\title{
Pycnogenol $^{\circledR}$ (bark extract from pinus pinaster) uses in prevention and treatment of cardiopathies
}

\section{Uso do Picnogenol ${ }^{\circledR}$ (extrato da casca do pinus pinaster) no tratamento e prevenção de cardiopatias}

Lucas Soares Bezerra1․ Natanael da Silva Bezerra-Junior². Marcelo Antônio Oliveira Santos-Veloso ${ }^{3}$. Fernando de Oliveira ${ }^{4}$. Ândrea Virgínia Chaves-Markman ${ }^{5}$.

1 Maurício de Nassau University, Recife, Pernambuco, Brazil. 2 Federal University of Pernambuco, Recife, Pernambuco, Brazil. 3 Federal University of Pernambuco; Recife, Pernambuco, Brazil. 4 Catholic University of Pernambuco, Recife, Pernambuco, Brazil. 5 Federal University of Pernambuco; Recife, Pernambuco, Brazil.

\begin{abstract}
Pycnogenol $^{\circledR}$ (Pyc) is an extract from a plant bark known as Pinus pinaster. Some studies have shown that Pyc can prevent oxidative damage, inhibit inflammatory cytokines and be used in the treatment of metabolic syndrome. This study aimed to review the state of the art of Pyc in the treatment of cardiovascular disease. The keywords "pycnogenol" and "cardiopathy" were searched on the PubMed, Scopus, The Cochrane Library, Scielo and Bireme databases. Studies involving animals or with no relation to cardiological conditions were excluded. The findings in the literature point Pycnogenol ${ }^{\circledR}$ as a promising substance in the treatment of cardiovascular conditions, as well as in other medical situations. Some studies have showed benefits in reduction of antihypertensive drugs dose and collateral effects, better control of diabetes, and reduction of cardiovascular risk factors. However, these results were obtained from studies with small sample of patients, limited follow-up and important biases. Further studies, such as larger clinical trials, are needed to elucidate the real risk-benefit of Pycnogenol ${ }^{\circledR}$ on treatment of cardiovascular diseases.
\end{abstract}

Keywords: Pinus. Heart diseases. Antioxidants.

\section{RESUMO}

Picnogenol ${ }^{\circledR}$ (Pyc) é um extrato da casca de uma planta conhecida como Pinus pinaster. Alguns estudos mostraram que o Pyc pode prevenir danos oxidativos, inibir citocinas inflamatórias e ser usado no tratamento da síndrome metabólica. Este estudo teve como objetivo rever o estado-da-arte sobre o tratamento de cardiopatias com o Pyc. Os termos "pycnogenol" e "cardiopatia" foram pesquisadas nos bancos de dados PubMed, Scopus, The Cochrane Library, Scielo e Bireme. Estudos envolvendo animais ou sem relação com condições cardiológicas foram excluídos. Os achados na literatura apontam o Pyc como uma substância promissora no tratamento de doenças cardiovasculares, bem como em outras condições médicas. Alguns estudos demonstraram benefícios na redução da dose de medicamentos anti-hipertensivos e seus efeitos colaterais, melhor controle do diabetes e redução dos fatores de risco cardiovascular. No entanto, esses resultados derivam de estudos com amostras pequenas de pacientes, acompanhamento limitado e que apresentam vieses importantes. Estudos adicionais, como grandes ensaios clínicos, são necessários para elucidar o risco-benefício real do Pycnogenol ${ }^{\circledR}$ no tratamento de cardiopatias.

Palavras-chave: Pinus. Cardiopatias. Antioxidantes.

Corresponding author: Lucas Soares Bezerra, Centro Universitário Maurício de Nassau, Rua Jonathas de Vasconcelos, 316, Boa Viagem, Recife, Pernambuco. CEP: 51021-140. Telefone: +55 81 3413-4611. E-mail: lucassbezerra@gmail.com

Conflict of interests: The authors have no conflicts of interest to declare.

Received: 30 Mar 2018; Revised: 06 Oct 2018; Accepted: 06 Oct 2018. 


\section{OVERVIEW}

Pycnogenol ${ }^{\circledR}$ (Pyc), or French maritime pine bark extract, is an extract from a plant bark known as Pinus pinaster (from class Pinopsida, order Pinales and family Pinaceae) ${ }^{1}$ that has been studied for different purposes, such as the treatment of osteoarthritis, neuropsychiatric conditions, cardiovascular diseases, and dermato-cosmetic therapies. ${ }^{2}$ Some of the most significant biological effects are: the protein-binding capacity, high structural mutability and function diversity. Also, the role of Pyc in the cellular antioxidant network, mediated by generegulated redox status, has been demonstrated. ${ }^{3}$

According to Viskupicova, ${ }^{2}$ some studies have shown that Pyc can prevent oxidative damage and restore the glucose level, which improves pathological oxidative state on diabetes. The isolated use of Pycnogenol ${ }^{\circledR}$ seems to decrease the production of IL-1 $\beta$ and the expression of IL-1 $\beta$ mRNA in RAW264.7 mice macrophages. These findings suggest the inhibition of inflammatory cytokines production during lung injury. ${ }^{4}$ Pyc applications in dermatology are mainly explained by the effects on prevention of UV radiation-induced skin damage, modulation of skin pigmentation and improvement of skin barrier function. ${ }^{5}$

In the treatment of osteoarthritis, changes on synovial fluid volume presented no statistically significant levels on randomized controlled study. However, pyc seems to have a chondroprotective effect. ${ }^{6}$ Other described properties of the Pyc include: coadjuvant function on treatment of metabolic syndrome disorders (especially diabetes), ${ }^{7}$ anti-inflammatory, anti-allergic and anticarcinogenic activities. ${ }^{4,8}$

This study aimed to review the state of the art of Pycnogenol ${ }^{\circledR}$ in the treatment of cardiovascular diseases in humans.

\section{METHODS}

We conducted a narrative review about Pycnogenol ${ }^{\circledR}$ general composition and therapeutic uses. We intended to focus on the latest advances in the treatment of cardiovascular diseases.

The survey was conducted in the following databases: PubMed, Scopus, The Cochrane Library, Scielo and Bireme, using the keywords "pycnogenol" and "cardiopathy". Articles in English, Spanish or Portuguese were analyzed.

Research with humans evaluating the effect of Pycnogenol ${ }^{\circledR}$ in patients with cardiopathies in all age groups were included.

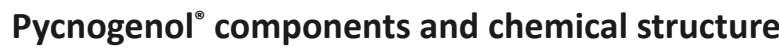

Pyc corresponds to an aqueous extract primarily composed by secondary metabolites such as flavonoids (Figure 1), phenolic acids, taxifolin, catechin and cinnamic acids and their glycosides. ${ }^{3,6}$ Some sugars, including glucose, xylose, and arabinose can be found in the extract, as well as inorganic substances, such as iron, calcium and potassium. ${ }^{9}$

Analysis of High Pressure Liquid Chromatography extract has demonstrated that major composition corresponds to flavonoids, which occur as dimers of catechin and epicatechin (40,9\%) (Figure 2), catechin monomers $(18,9 \%)$ and trimeric and tetrameric species of proanthocyanidins $(19 \%){ }^{3}$

The antioxidant properties of Pyc can be explained by the action of hydroxyl groups in the aromatic rings, which might deactivate free radicals, including the small hydroxyl and lipid peroxyl radicals. The main deactivation mechanism is the stabilized phenoxyl radicals formation, ${ }^{8}$ which are less susceptible to oxidation in comparison, for example, to cyclopentadienyl radicals. ${ }^{10}$

Figure 1. Flavonoid general structure.

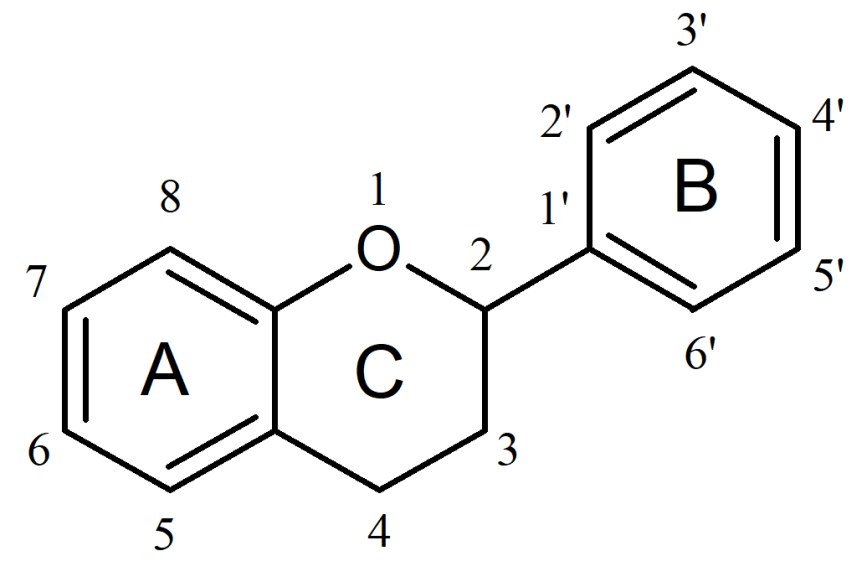

Figure 2. Dimeric structure formed by the subunits epicatechin and catechin.<smiles>[R]c1c(O)cc(O)c2c1O[C@H](c1ccc(O)c(O)c1)[C@H](O)[C@H]2c1c(O)cc(O)c2c1O[C@H](c1ccc(O)c(O)c1)[C@@H](O)C2[R]</smiles>

\section{Cardiovascular diseases and Pycnogenol ${ }^{\circ}$}

Oxidative stress is related to the development of several unhealthy conditions, such as cardiovascular diseases. Low density lipoproteins (LDL) oxidation and poly-unsaturated fatty acids in the cell membranes are some of the main mechanisms that explain the development of cardiac and arterial illnesses. ${ }^{11}$ 
Among the potential applications of Pyc, it is specially relevant for the management of vascular issues, considering its major role on endothelial function improvement and venous insufficiency treatment. ${ }^{9}$ Pyc therapeutic doses varies considerably and depends on the patient's clinical condition (Table 1).

Table 1. Indicated dosage of Pycnogenol ${ }^{\circledR}$ on the treatment of vascular/cardiovascular conditions. ${ }^{10}$

\begin{tabular}{ll}
\hline Condition & Indicated dosage \\
\hline Chronic Venous Insufficiency & $150-360 \mathrm{mg} /$ day \\
Diabetes & $50-200 \mathrm{mg} /$ day \\
Hypertension & $100-200 \mathrm{mg} /$ day \\
Retinopathy & $20-160 \mathrm{mg} /$ day \\
Erectile dysfunction & $120 \mathrm{mg} /$ day \\
\hline
\end{tabular}

Carotid echogenicity and femoral atherosclerotic plaques were evaluated on a study ${ }^{12}$ with 79 subjects, of whom 36 were on a Standard Management (SM) system (with lifestyle changes) and received a combination of Pyc (150 mg/day) and Centellicum (450 mg/day), and the control group was only under SM therapy. Treatment was administered for 6 months and the plaque structure and echogenicity were evaluated by high-resolution ultrasound. Cholesterol was reduced in both groups (a decrease of $16.8 \%$ with supplement vs $18.7 \%$ with only SM) with no statistical difference. Plasma free radicals were significantly decreased, and plaque stability index and echogenicity were increased in intervention group while none of the three indicators had significant changes compared to the control group.

According to an observational pilot conducted by Belcaro et $\mathrm{al}^{13}$ with 824 patients who had a stenotic atherosclerotic plaque ( $>50-60 \%$ ), a beneficial effect of Pyc on dosage of $100 \mathrm{mg} /$ day was found. The highest efficiency could be considered on Pyc $100 \mathrm{mg}$ /day plus total triterpenic fraction of Centella asiatica (TTFCA) $100 \mathrm{mg} /$ day, which was higher than on groups taking Pyc $50 \mathrm{mg} /$ day, Pyc $100 \mathrm{mg} /$ day, aspirin ${ }^{\circledR} 100 \mathrm{mg}$ /day or $\operatorname{aspirin}^{\circledR} 100 \mathrm{mg} /$ day plus Pyc $100 \mathrm{mg} /$ day.

A study ${ }^{14}$ evaluating capillary filtration was performed within eight weeks by analyzing the effect of Pyc in preventing edema caused by antihypertensive therapy, in a group of patients with essential hypertension under a calcium antagonist or angiotensin converting enzyme inhibitor therapy. Pycnogenol ${ }^{\circledR}$ regulates this type of edema, helping to prevent and limit microcirculation long-term damage in hypertensive patients. Also, antihypertensive drugs dosage reduction can be achieved, in most patients. In addition, Pycnogenol ${ }^{\circledR}$ significantly reduces cough, a common adverse effect of the use of AngiotensinConverting Enzyme (ACE) inhibitors.

\section{REFERÊNCIAS}

1. Chamberlain SA, Szöcs E. Taxize: taxonomic search and retrieval in R. F1000Research. 2013;2:191.
In a double-blind randomized trial, forty-eight ${ }^{15}$ subjects with type 2 diabetes and mild to moderate hypertension were treated with ACE inhibitors. They were randomly allocated to receive Pycnogenol ${ }^{\circledR}$ pills or placebo for 12 weeks. Blood pressure (BP) was measured at a 2-weeks interval and the dose of the pretrial ACE inhibitor was left unchanged, reduced to $50 \%$ or brought back to the pre-study dosage until stable BP. Fasting glycemia, LDL, glycosylated hemoglobin (HbA1c), and serum endothelin-1 were measured monthly. Treatment with Pyc achieved BP control in $58.3 \%$ of subjects at the end of 12 weeks with a $50 \%$ reduction in the pretrial individual dose of ACE inhibitors. Plasma endothelin-1 decreased $3.9 \mathrm{pg} / \mathrm{ml}$ versus $0.5 \mathrm{pg} / \mathrm{ml}$ in the control group. The mean HbAlc fell $0.8 \%$ versus $0.1 \%$ in the control group. Fasting glycemia decreased by $23.7 \mathrm{mg} / \mathrm{dL}$ versus $5.7 \mathrm{mg} / \mathrm{dL}$ in the control group. Therefore, Pycnogenol ${ }^{\circledR}$ resulted in better control of diabetes, reduction of cardiovascular risk factors, and reduction of antihypertensive drug use.

In a double-blind, placebo-controlled, cross-over study, ${ }^{16}$ twenty-three patients with coronary artery disease (CAD) took Pyc (200 mg/day) pill for 8 weeks followed by placebo or vice versa, adjunct to standard cardiovascular therapy. Between the two treatment periods, the 2-week washout period was scheduled. At the baseline and after each treatment period, non-invasive evaluation of endothelial function was performed through the study of flow-mediated dilation (FMD) of the brachial artery using a high-resolution ultrasound, oxidative stress biomarkers and inflammation, platelet adhesion and blood pressure monitoring $24 \mathrm{~h}$. In patients with CAD, treatment with Pyc was associated with an improvement in FMD.

\section{Cytotoxic properties and contraindications}

By now, there are no formal contraindications for Pyc. However, as a security measure, it should not be prescribed in lactation and on the first trimester of pregnancy (Risk B) and also in case of hipersenbility to any component of Pyc. ${ }^{9}$

\section{CONCLUSIONS}

Literature findings point Pycnogenol $^{\circledR}$ as a promising substance in the treatment of cardiovascular conditions. Benefits in the reduction of antihypertensive drugs dose and their collateral effects, better control of diabetes, and reduction of cardiovascular risk factors are convergent findings pointed out by different studies. However, these benefits were demonstrated from studies with small sample, limited followup and presenting important biases. Therapeutic benefit of pyc is based on weak evidence and limited studies. In addition, there is scarce data about safety end-points and collateral effects. Further studies, such as large clinical trials, are needed to elucidate the real risk-benefit of Pycnogenol ${ }^{\mathbb{}}$ on treatment of cardiovascular diseases. 
dysregulation. Phytother Res. 2017;31(11):1702-7.

3. D'Andrea G. Pycnogenol: a blend of procyanidins with multifaceted therapeutic applications? Fitoterapia. 2010;81(7):724-36.

4. Xia YF, Zhang JH, Xu ZF, Deng XM. Pycnogenol, a compound isolated from the bark of pinus maritime mill, attenuates ventilatorinduced lung injury through inhibiting NF- $\mathrm{kB}$-mediated inflammatory response. Int J Clin Exp Med. 2015;8(2):1824-33.

5. Grether-Beck S, Marini A, Jaenicke T, Krutmann J. French maritime pine bark extract (Pycnogenol $\left.{ }^{\circledR}\right)$ effects on human skin: clinical and molecular evidence. Skin Pharmacol Physiol. 2016;29:13-17.

6. Jessberger S, Högger P, Genest F, Salter DM, Seefried L. Cellular pharmacodynamic effects of Pycnogenol ${ }^{\circledR}$ in patients with severe osteoarthritis: a randomized controlled pilot study. BMC Complement Altern Med. 2017;17:537.

7. Gulati OM. Pycnogenol ${ }^{\circledR}$ in metabolic syndrome and related disorders. Phytother Res. 2015;29(7):949-68.

8. Alves AM, Alves EP, Mello JM, Bespalhok DN, Yamamoto E, Crhistmann C, et al. Propriedades terapêuticas do Picnogenol em alterações funcionais geradas pelo diabetes mellitus. Revista Uningá. 2015;43(1):66-70.

9. Oliff HS. Scientific and clinical monograph for PYCNOGENOL ${ }^{\circledR}$. Austin: American Botanical Council; 2010 [Acesso em: 15 Jun 2018]. Monography. Disponível em: http:// abc.herbalgram.org/site/DocServer/Pycnog_FullMono 120809 LOW.pdf?docID=1741
10. Dellinger B, Lomnicki S, Khachatryan L, Maskos Z, Hall RW, Adounkpe J, et al. Formation and stabilization of persistent free radicals. Proc Combust Inst. 2007;31(1):521-8.

11. Schoonees A, Visser J, Musekiwa A, Volmink J. Pycnogenol $\AA$ (extract of French maritime pine bark) for the treatment of chronic disorders. Cochrane Database Syst Rev. 2012;4:CD008294.

12. Belcaro G, Cornelli U. Variations in echogenicity in carotid and femoral atherosclerotic plaques with Pycnogenol+Centella asiatica supplementation. Int J Angiol. 2017;26(2):95-101.

13. Belcaro G, Ippolito E, Dugall M, Hosoi M, Cornelli U, Ledda $\mathrm{A}$, et al. Pycnogenol ${ }^{\circledR}$ and Centella asiatica in the management of asymptomatic atherosclerosis progression. Int Angiol. 2015;34(2):150-7.

14. Belcaro G, Cesarone MR, Ricci A, Cornelli U, Rodhewald P, Ledda A, et al. Control of edema in hypertensive subjects treated with calcium antagonist (Nifedipine) or angiotensin-converting enzyme inhibitors with Pycnogenol. Clin Appl Thromb Hemost. 2006;12(4):440-4.

15. Zibadi S, Rohdewald PJ, Park D, Watson RR. Reduction of cardiovascular risk factors in subjects with type 2 diabetes by Pycnogenol supplementation. Nutr Res. 2008;28(5):315-20.

16. Enseleit F, Sudano I, Périat D, Winnik S, Wolfrum M, Flammer AJ, et al. Effects of Pycnogenol on endothelial function in patients with stable coronary artery disease: a double-blind, randomized, placebo-controlled, cross-over study. Eur Heart J. 2012;33(13):1589-97.

\section{Como citar:}

Bezerra LS, Bezerra-Junior NS, Santos-Veloso MA, Oliveira F, Chaves-Markman AV. Pycnogenol ${ }^{\circledR}$ (bark extract from pinus pinaster) uses in prevention and treatment of cardiopathies. Rev Med UFC. 2019 jul-set;59(3):44-47. 